\title{
Přímá transaortální implantace chlopně do aortální pozice u nemocného po chirurgické revaskularizaci myokardu
}

\author{
Josef Veselka', Marek Šetina², Martin Malý', Kateřina Linhartová', Petr Hájek', Tomáš Vymazal, \\ Giuseppe Bruschi ${ }^{4}$ \\ 'Kardiologická klinika, 2. lékařská fakulta Univerzity Karlovy a Fakultní nemocnice v Motole, Praha, Česká republika \\ ${ }^{2}$ Kardiochirurgická klinika, 2. lékařská fakulta Univerzity Karlovy a Fakultní nemocnice v Motole, Praha \\ ${ }^{3}$ Klinika anesteziologie a intenzivni medicíny, 2. lékařská fakulta Univerzity Karlovy a Fakultní nemocnice v Motole, Praha \\ ${ }^{4}$ Dipartimento Cardiologico, Ospedale Niguarda Ca' Granda, Milano, Italia
}

Adresa: Prof. MUDr. Josef Veselka, CSc., Kardiologická klinika, 2. LF UK a FNM, V Úvalu 84, 15000 Praha 5, e-mail: josef.veselka@fnmotol.cz

Katetrizační implantace aortální chlopně do aortální pozice (TAVI) se stala alternativou chirurgické léčby významné aortální stenózy (AS) u pacientů s nepřiměřeně vysokým rizikem chirurgické náhrady chlopně. Tradiční přístupovou cestu k aortální chlopni představuje prrístup transfemorální, alternativně se využívají přístupy transsubklaviální a transapikální - přístup přes hrot levé komory srdeční. ${ }^{1}$

U 78letého nemocného s těžkou AS a po již provedené chirurgické revaskularizaci myokardu s těžkou chorobou tři tepen a průchodným žilním štěpem na ramus

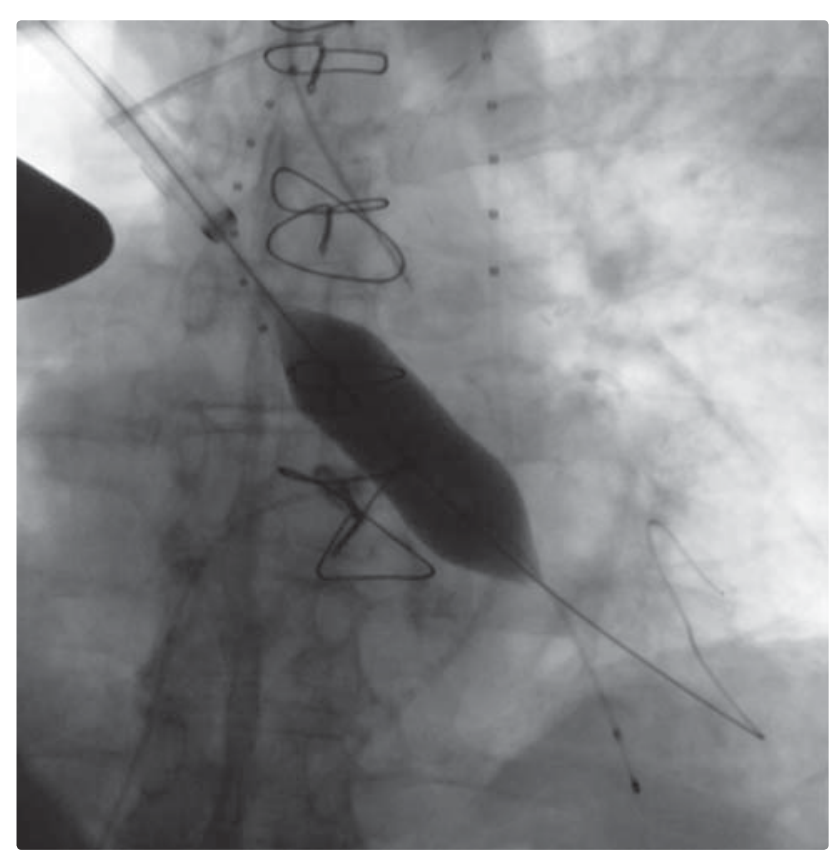

Obrázek 1 Balonková aortální valvuloplastika chlopně provedená cestou $18 \mathrm{~F}$ zavaděče $\mathrm{v}$ ascendentní aortě marginalis a s mamarokoronárním bypassem na ramus interventricularis anterior nebylo možno pro obliterující aterosklerózu využít žádný z tradičních prrístupových cest $\mathrm{k}$ aortální chlopni $\mathrm{v}$ rámci TAVI. Plánovaně jsme tedy provedli implantaci aortální protézy typu CoreValve $29 \mathrm{~mm}$ (Medtronic, USA) cestou pravostranné minithorakotomie ve 2. mezižebří parasternálně s odhalením ascendentní aorty a její kanylací pomocí $18 \mathrm{~F}$ zavaděče (obrázky 1-5). Implantací chlopně jsme eliminovali tlakový gradient na aortě a výsledně byla prrítomna pouze lehká aortální

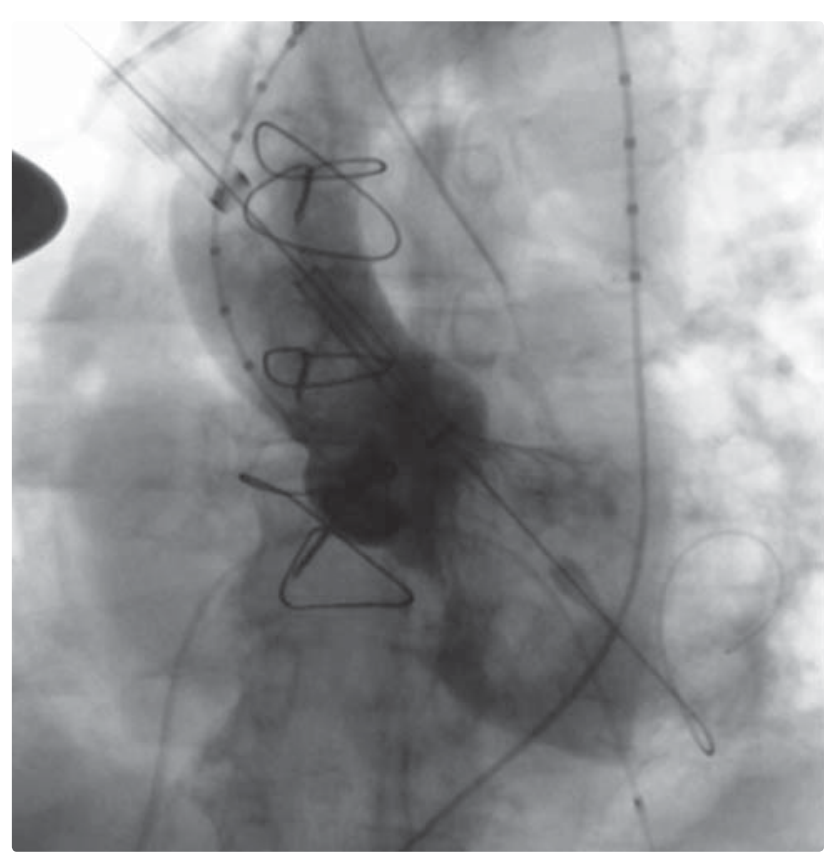

Obrázek 2 Částečně rozvinutá chlopeň CoreValve v aortální pozici 


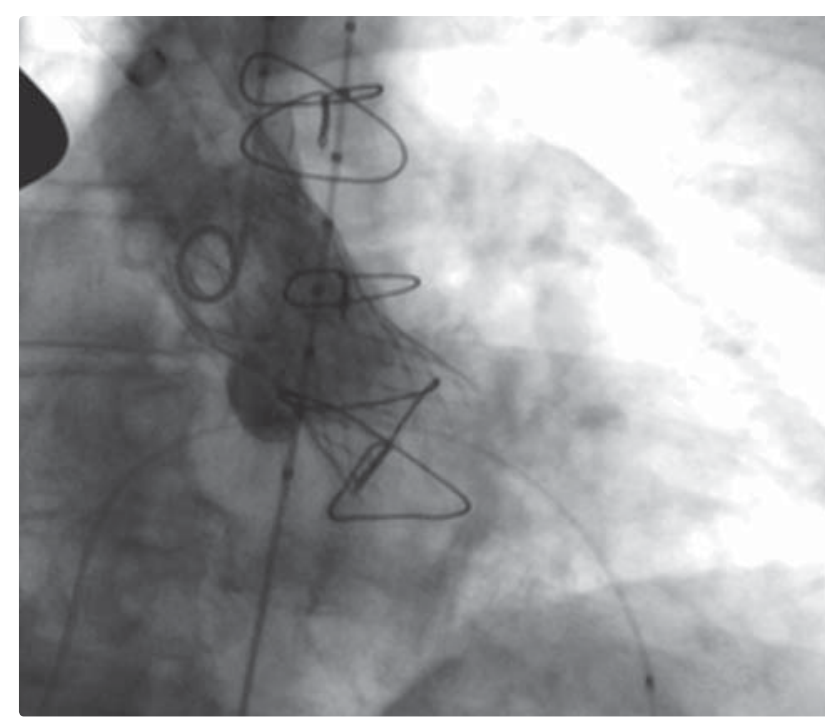

Obrázek 3 Aortografie po implantaci chlopně s lehkou aortální regurgitací

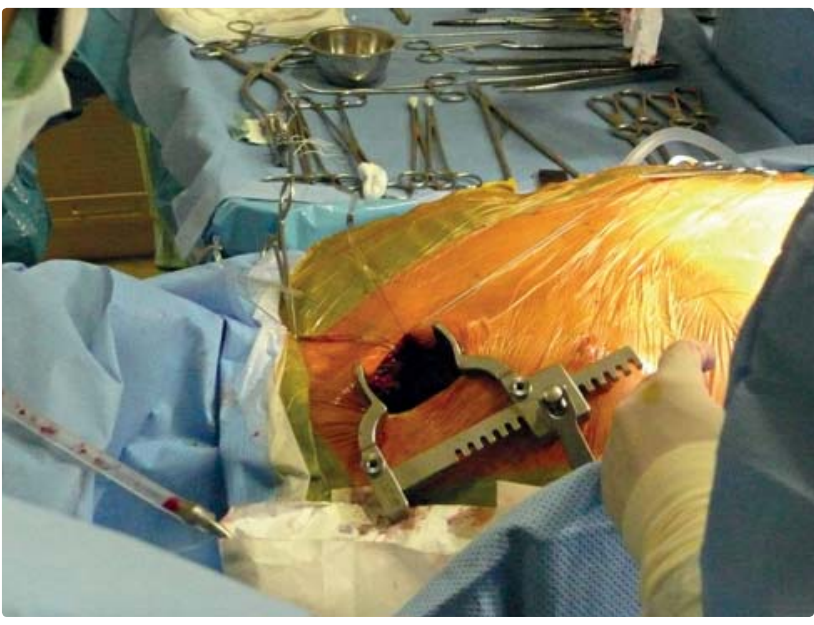

Obrázek 4 Operační pole

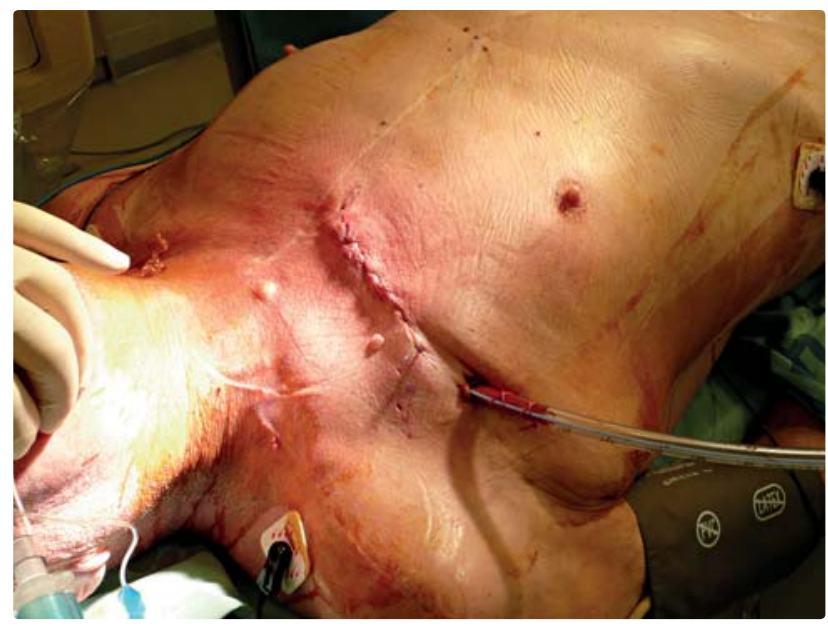

Obrázek 5 Sutura pravostranné přední minithorakotomie se zavedeným drénem bezprostředně po výkonu

regurgitace. Pacient byl propuštěn do domácího ošetřování za deset dní po výkonu.

Př́má transaortální TAVI představuje novou alternativu při terapii těžké AS u vysoce rizikových pacientů s obliterující aterosklerózou nedovolující využití tradičních prŕstupových cest $\mathrm{k}$ aortální chlopni. ${ }^{1}$ Hybridní výkony kardiologicko-kardiochirurgických týmů budou při terapii nejtěžších kardiovaskulárních pacientů stále častější.

\section{Literatura}

1. Bruschi G, De Marco F, Fratto P, et al. Alternative approaches for trans-catheter self-expanding aortic bioprosthetic valves implantation: single-center experience. Eur J Cardiothorac Surg 2011;39:151-158.

Došlo do redakce: 6. 6. 2011

Prijato: 30. 8. 2011 